\title{
ANÁLISE DA PRÁTICA DO ATIVISMO JUDICIÁRIO NO BRASIL, A PARTIR DAS GARANTIAS DA DEMOCRACIA, PRINCÍPIO DA SEPARAÇÃO DOS PODERES E CONTROLE DE CONSTITUCIONALIDADE
}

\author{
José Marcos Miné Vanzella \\ Rafael Pinto dos Santos
}

\begin{abstract}
Resumo:
O presente artigo objetiva a análise crítica, com metodologia dedutiva, bibliográfica e documental, da prática do ativismo judicial brasileiro, a partir das garantias da democracia, do princípio da separação dos poderes e do controle da jurisdição constitucional. Expõe o conceito de democracia e seu nexo com o direito exposto entre outros por Habermas. $\mathrm{O}$ ativismo judiciário, por violar a tecnicidade do exercício jurisdicional tenciona direito e democracia. Põe em risco a separação dos poderes, independente de agir a favor ou contra a política do governo, pondo em risco a democracia e os direitos fundamentais que não podem ser barganhados.
\end{abstract}

Palavras-chave: Democracia, Constituição, Ativismo Judicial, Separação dos Poderes, Direitos fundamentais.

\section{ANALYSIS OF THE PRACTICE OF JUDICIAL ACTIVISM IN BRAZIL, FROM THE GUARANTEES OF DEMOCRACY, THE PRINCIPLE OF THE SEPARATION OF POWERS AND CONTROL OF CONSTITUTIONALITY}

\begin{abstract}
:
This article aims to critically analyze, with deductive, bibliographic and documentary methodology, the practice of Brazilian judicial activism, based on the guarantees of democracy, the principle of separation of powers and the control of constitutional jurisdiction. It exposes the concept of democracy and its connection with the right exposed by Habermas, among others. Judicial activism, for violating the technicality of the jurisdictional exercise, intends law and democracy. It jeopardizes the separation of powers, regardless of whether they act for or against government policy, endangering democracy and fundamental rights that cannot be bargained for.
\end{abstract}

Keywords: Democracy, Constitution, Judicial Activism, Separation of Powers, Fundamental rights.

\section{INTRODUÇÃO}

Na conjuntura jurídica brasileira corrente, esporádicas são as palavras que têm sido motivo de tamanha desordenação como estas duas: "ativismo judicial". A repercussão dessa propagação semântica é tão comum quanto sombroso: o obscurecimento total sobre o acontecimento que elas procuram instituir. A ausência de transparência é tal que, nos dias de hoje, tanto a direita como a esquerda empregam a expressão para elucidar concepções judiciais diretamente antagônicas. Evidencia-se que não existe nenhuma novidade nesse 
modelo de embate. Nos EUA, a forte contenda de convicções entre Democratas e Republicanos aumenta as polêmicas sobre o assunto.

E além disso: há setores da doutrina e ainda especialmente do Judiciário que, primorosamente, tutelam a observância cotidiana do direito, o comportamento ativista, sem ao menos exprimir o que realmente está se falando. Por essas e outras causas é que se fazem essenciais algumas apreciações introdutórias acerca da presente temática.

Nesse contexto, a indagação que se almeja responder ao final do atual trabalho científico é o seguinte: $\mathrm{O}$ ativismo judicial está em conformidade com o papel do judiciário no Estado Democrático de Direito? Em outras palavras, a partir da necessária compreensão do nexo entre direito e democracia, o ativismo judicial brasileiro, está de acordo com as garantias da democracia, do princípio da separação dos poderes e do controle da jurisdição constitucional?

Em vista disso, o presente escrito tem por propósito geral proferir uma análise crítica no que corresponde ao ativismo judicial e a separação de poderes no sistema jurídico brasileiro, levando em consideração os conhecimentos de Jürgen Habermas. Já como objetos particulares, o que se pretende é compreender a definição de democracia; a aclamação do princípio da separação de poderes; a colaboração dos Estados Unidos da América no sistema checks and balances e, por último, examinar os limites da interpretação constitucional e o controle de constitucionalidade na circunstância do ativismo judicial.

Para embasar o corrente artigo científico, serão utilizadas pesquisas bibliográficas e documentais (fonte secundária). Cabe salientar que o tipo de raciocínio a ser empregado será o método dedutivo, já que parte do geral para o particular.

Dentro do cenário retratado, vale destacar que o vigente estudo não tem o intuito de esgotar o assunto em pauta, mas sim mencionar detalhes importantes do conteúdo, de maneira a principiar uma discussão e colaborar para a estruturação de uma compreensão a respeito da matéria, sem o objetivo de elaborar uma ferramenta mágica para esclarecer o problema.

\section{COMPREENDENDO A DEMOCRACIA}

Antes de abordar o tema principal desse artigo, é relevante realizar alguns comentários em relação à Democracia. Com efeito, essa não é um termo manifesto, sendo a sua conceituação origem de incontáveis discussões, porque algumas hipóteses se destinam para o procedimento e outras para a substância quando a finalidade é descrevê-la. Torna-se interessante mencionar as visões de Vanzella e Marquette (2018, p. 151) quanto à necessidade da democracia: "As ideias de Habermas, sobre sociedade civil e esfera pública, só podem ser concebidas adequadamente na dimensão democrática e em sua conexão com o direito, em especial com as garantias jurídicas”. Para o autor alemão existe uma conexão interna entre direito e democracia. Só na democracia se pode garantir os direitos fundamentais ao conjunto dos cidadãos.

Porém, por outro lado, inspirando-se em Chantal Mouffe, Juliana Brina Corrêa Lima de Carvalho, afirma: "diferentemente, democracia e constitucionalismo estão em estado de conflito permanente. A tensão entre Lei e Política, constitucionalismo e democracia não pode ser bipartida entre órgãos, porquanto está presente em todos os momentos de decisão, tanto judicial quanto legislativa" (2013, p.703). Uma abordagem realista e sociológica pode fazer tal afirmação, porém se é correto que o direito se desenvolve entre facticidade e validade, há que se perguntar se a entrada indiscriminada da política no Supremo Tribunal Federal não o desvia de sua função fundamental de protetor dos fundamentos e das regras do jogo democrático. $\mathrm{O}$ alastramento do jogo funcional da política administrativa do poder, por cima 
da distinção dos papeis dos poderes não pode comprometer a legitimidade do Estado Democrático de Direito?

Os diversos entendimentos que intencionam fundamentar a soberania popular distinguem-se entre si, em consequência da maneira que cada um apresenta o conteúdo da moral: as que distanciam esta da política, a democracia liberal, e as que admitem uma vinculação entre as duas, a democracia social/participativa (NINO, 1997, p. 101-102).

Carlos Santiago Nino (1997, p. 103-104) exprime que a conformação como a questão moral é introduzida, as formulações sobre a democracia podem adquirir dois formatos diversos: o primeiro menciona a Democracia Liberal/Constitucional, caracterizada pela ausência do assunto moral; já o segundo representa a Democracia Social/Participativa, cujo processo democrático está relacionado com a moral. Inúmeras alegações de que ambas as perspectivas estão incorretas são descritas pelo citado autor, ao aventar a teoria da democracia deliberativa, e que esta seria uma definição normativa incompleta estipulada por uma suposição moral.

Consoante o aludido autor, os demais pensamentos de uma soberania popular estariam repletos de imperfeições e apenas a percepção de democracia deliberativa seria capaz de superar tais deslizes. Nessa ótica, a moral e a política seriam níveis correlacionados e o governo popular consistiria em um procedimento mais confiável para a indicação dos valores normativos. Com a democracia deliberativa, por intermédio da análise das considerações de John Rawls (entende que a validade de um princípio moral está relacionada com um pensamento individual) e Jürgen Habermas afirma que somente um debate público é a maneira verdadeira e segura de alcançar o conhecimento moral, Nino (1997, p. 154-155) mantém um sentido construtivista sobre como ocorre a compreensão das convicções morais.

Nino (1997, p. 202) aponta que a democracia deliberativa evidencia muitos favorecimentos quando equiparada com as outras designações de soberania popular, com a sua relevância epistêmica. Inicialmente, por causa desse ponto de vista, os preceitos legais aprovados democraticamente não teriam finalidades razoáveis para esclarecer atos/deliberações, e sim premissas epistemológicas. Dessa forma, as normas não são em si mesmas razões para atuar/decidir, mas elas procedem de razões para acreditar que há motivos para atuar/decidir. Em segundo lugar, a democracia deliberativa enfrenta melhor os inconvenientes de determinações gerais. Outro aspecto proveitoso da definição exposta por Nino é que ele resolve o confronto entre a constatação de direitos (conteúdo) e a democracia (processo), em virtude dessa percepção, o valor desta é incontestável conforme a sua aptidão nas escolhas dos assuntos morais, como, por exemplo, a temática, a abrangência e a ordenação dos direitos. Além do mais, ela proporciona a conservação da atividade constitucional desde que atestada por juízos morais independentes.

Em um cenário análogo, Bruce Ackerman (2006, p. 16) também exterioriza uma noção mista de soberania popular. Ressaltando os erros tanto da democracia monista (democracia contra direitos) como dos fundamentalistas de direitos (direitos contra democracia), Ackerman apresenta uma ideia de democracia dualista, que evidencia uma posição de conciliação na elaboração da legislação e propicia o entendimento dos fundamentalistas para os direitos alcançarem o êxito sem infringir a visão dos monistas. Nessa conceituação, o escritor diferencia duas ocasiões de efetuação de juízos que podem transcorrer em um governo popular: as escolhas praticadas pela cidadania mobilizada (decisões fundamentais); e as resoluções adotadas pelo governo (decisões de política rotineira). Por conseguinte, sendo a jurisdição constitucional compreendida como a função atribuída ao Poder Judiciário de preservar as deliberações selecionadas pela sociedade contrárias as decisões de política habitual, tornaria plausível harmonizar a democracia e a Constituição. 
Sendo assim, sem maiores divergências, para o corrente estudo revela-se satisfatório o consenso de democracia como um "lugar" que oportunize o pensamento questionador para que o debate público seja o melhor possível, consentindo um vasto envolvimento no procedimento deliberado de todos os potencialmente atormentados pela decisão.

Não obstante, cumpre frisar que a democracia representativa atravessa uma instabilidade, cujas as motivações podem ser constatadas na baixa qualidade do debate público, e ainda em uma situação de indiferença política que penetra e se experimenta presente na maior parte da população, entre outros fatores. Ainda, na circunstância brasileira, a sociedade e os profissionais da área jurídica precisam se restabelecer da derrocada democrática ocasionada pelos governos militares; e ter sempre na consciência que os integrantes da Assembleia Constituinte, no ano de 1987, empenharam-se pela redemocratização do país com a promulgação da atual Carta Política em 1988.

\section{CONSAGRAÇÃO DO PRINCÍPIO DA SEPARAÇÃO DE PODERES}

Malgrado seja inquestionável a colaboração de Locke para a idealização do princípio da separação de poderes, a elaboração desse instituto é obviamente conferida a Montesquieu, que ordenou de maneira esquematizada a teoria e alavancou o Judiciário a um poder autossuficiente. Montesquieu residiu na cidade britânica de Londres, entre os anos 1728 e 1731, tendo pesquisado o sistema político Inglês que apontou, no fim, o seu exemplo de estruturação do Estado (FERREIRA FILHO, 2009, p. 251).

Verifica-se, em "O Espírito das Leis", no Livro Décimo e Capítulo VI, nomeado "Da Constituição da Inglaterra", a manifesta influência de Montesquieu no legado de Locke, onde apresenta a separação de poderes. A nação inglesa alcançava na sua Constituição a alusão da salvaguarda da emancipação política de seus administrados e essa procura pelo consentimento de liberdade persuadiu Montesquieu, que descobriu na segmentação das funções do Estado, precisamente, uma maneira de inibir os atentados cometidos e também uma oportunidade de admitir a independência dos cidadãos.

A incumbência de julgar, na Inglaterra, estava extremamente próxima do encargo administrativo, porque independentemente da existência dos Tribunais da Common Law, integrados por juízes parcialmente insubmissos, sentenciar era uma das atribuições do rei. Por seu turno, a Câmara dos Lordes efetuava as audiências de jurisdição definitiva, sendo vinculados ao Parlamento.

Diversamente de Locke, Montesquieu arquitetou o Judiciário como um poder emancipado no que concerne ao Executivo e Legislativo, pois presumia que se não fosse distanciado dos restantes, não existiria liberdade para a realização de julgamentos imparciais. E ocorreriam violações, caso mostra-se coincidência com o Poder Legislativo, já que o controle sobre a vida e a liberdade das pessoas estaria perante a responsabilidade dos representantes do povo. Por outro lado, o magistrado possuiria a mesma rigidez de um déspota, se a função de sentenciar estivesse relacionada ao Poder Executivo. Noticia, ainda assim, que "os juízes da nação são apenas a boca que pronuncia as palavras da lei; são seres inanimados que não podem moderar nem sua força, nem seu rigor." (MONTESQUIEU, 2000, p. 175).

Dessa forma, explica Manoel Messias Peixinho (2008, p.15-16):

Nas obras de Montesquieu (1689-1755) há rica e inesgotável fonte de inspiração teórica sobre limites do poder e da garantia da liberdade política, por meio da legalidade, da separação dos poderes e da relação da lei com a liberdade. A principal 
ênfase recai na consagração de algumas garantias processuais de defesa da liberdade e do papel das forças armadas. Foi, também, significativa a influência na Declaração de 1789 e nas constituições posteriores a distinção estabelecida por Montesquieu entre liberdade política e sua relação com a Constituição e o cidadão, ou entre princípios de organização dos poderes e direitos humanos. A liberdade política vista na Constituição não seria meramente um princípio de organização, mas um direito à participação. Montesquieu, inspirado na teoria esposada por John Locke, entende que os Poderes Legislativo, Executivo e Judicial devem ser atribuídos a pessoas diferentes, sem, contudo, pontuar rigorosa separação entre as funções. Em Montesquieu há verdadeira harmonia que enseja a atribuição conjunta e indivisível de três órgãos, quer dizer, a com soberania de três órgãos políticos.

Os insurgentes franceses e os próprios americanos acolheram os pensamentos de Montesquieu, enaltecendo a separação de poderes à exigência imprescindível para o desenvolvimento de Estados Constitucionais, do mesmo jeito que foi estipulado no decorrer da Revolução Francesa no documento da Declaração Universal dos Direitos do Homem e do Cidadão, prevista em seu art. 16 "A sociedade em que não esteja assegurada a garantia dos direitos nem estabelecida a separação dos poderes não tem Constituição" (DECLARAÇÃO DE DIREITOS DO HOMEM E DO CIDADÃO, 1789).

O presente princípio contribuiu significativamente na implementação do Estado de direito consoante os entendimentos de Mendes, Coelho e Branco (2009, p. 177): “[...] o princípio da separação dos poderes adquiriu o status de uma forma que virou substância no curso do processo de construção e de aprimoramento do Estado de Direito [...]".

Nessa perspectiva, em conformidade com Jürgen Habermas (2010, p. 300), na inteligência da teoria do discurso, é determinada uma incompatibilidade no entrelaçamento das funções do Estado para a racionalidade da divisão de poderes: em seu funcionamento, o Executivo, que não deve se utilizar das estruturas normativa da lei e da justiça, submete-se à autoridade parlamentar e judicial, distanciando da viabilidade de uma modificação dessa convivência, ou melhor, uma gerência das outras duas atribuições por intermédio do Executivo. Logo, quem contempla Carl Shmitt e afirma o presidente do Reich, isto é, o lugar mais alto do encargo administrativo, como "guarda da constituição", modifica em seu oposto a concepção da divisão de poderes no governo democrático. A coerência da separação de responsabilidades recomenda sua composição auto reflexiva à legislação - embasada na teoria da argumentação - de forma similar ao da justiça e que se a revista com a capacidade da contenção de sua própria tarefa.

Carvalho reconhece a crítica feita a ponderação de Alexy baseada no resultado natural da diferenciação entre regras e princípios no qual: "Princípios seriam equiparados a valores, e por isso seriam otimizáveis, e vice-versa" (2013, p 701). Ela entende que nesta perspectiva, não se discute por que princípios deveriam ser concebidos a partir desse atributo teleológico a serem realizados na maior medida possível. Em sua conclusão ela deixa claro que:

Uma concepção axiológica das normas não apresenta, porém, o potencial de universalização contido nos discursos sobre a correção das normas, uma vez que está enraizada em preferências. Tal concepção conduz, pois, a uma colonização do mundo da vida pelo Poder Judiciário, com a expansão da racionalidade instrumental, desalojando a racionalidade comunicativa e gerando uma crise de legitimidade do direito. Deixa-se de falar em adequabilidade, e passa-se a falar em preferibilidade, de modo que os princípios não mais indicam o que é devido, mas o que é preferível, e corre-se o risco de se confundir direitos com bens que podem ter sua aplicação negociada conforme as preferências da autoridade que decide. (2013, p.702). 
O deslocamento dos princípios para o campo axiológico retira-lhes a necessária universalidade e obrigatoriedade. Colocando os fundamentos do Estado à mercê do jogo de interesses políticos particulares.

Porém, a autora não percebe que ao entender com Mouffe que a teoria da argumentação jurídica apenas camufla a decisão hegemônica, reintroduz a colonização do mundo da vida que critica na abordagem axiológica pela porta da frente do STF. Ao entender que democracia e constitucionalismo estão em conflito permanente e rejeitar a distinção entre os papeis institucionais da divisão dos poderes coloca em risco o pacto constitucional. Ao rejeitar essa divisão de papeis: "a) do Legislativo como o centro vivo de um Estado Democrático de Direito, a sede por excelência da política; b) do Judiciário como centro vivo do constitucionalismo e da_aplicação técnica da lei, [...]”. (2013, p.703). Ela reintroduz política e valoração particular nas decisões judiciais ensejando a imposição da maioria às garantias constitucionais, espanta a necessária universalidade e obrigatoriedade que são garantias da legitimidade das regras do jogo.

Diferentemente, pode-se refletir, guardando a distinção dos papeis institucionais e o potencial de universalização do discurso, que democracia e constitucionalismo oscilam entre conflito e consenso. Normativamente não se pode admitir, que interesses políticos de grupos particulares se sobreponham através de decisões do STF ao seu papel de garantidor da constituição e do Estado Democrático de Direito.

Atualmente, a compreensão adequada do princípio da separação dos poderes demanda entendimentos conforme as diferentes vivências constitucionais, utilizando-se da exegese na aplicação da doutrina constitucional e da legislação (MENDES; COELHO; BRANCO, 2009, p. 178). Tal princípio está previsto na Lei Política nacional, no art. $2^{\circ}$, com a determinação expressa de independência e harmonia entre os Poderes da União. Além disso, caracteriza-se como uma das cláusulas pétreas do arcabouço jurídico nacional, segundo o art. $60, \S 4^{\circ}$, III da Constituição. (BRASIL, 1988).

Cumpre frisar as palavras proferidas pelo ministro Luiz Fux, atual presidente do STF, na palestra inaugural do VIII Fórum Jurídico de Lisboa, que aconteceu no mês de novembro de 2020, enaltecendo a relevância do princípio da separação dos poderes para a preservação do Estado Democrático de Direito, proporcionando uma simetria entre os Poderes. (FUX, 2020).

\section{A COLABORAÇÃO NORTE-AMERICANA: “CHECK AND BALANCES”}

A teoria da separação de poderes de Montesquieu foi amplamente empregada não apenas no continente europeu mas também nos Estados Unidos, onde percebe-se nitidamente sua interferência na bibliografia estadunidense, sendo capaz de citar a obra "Comentários ao Espírito das Leis de Montesquieu", editada em 1811, por disposição de Thomas Jefferson cujas repercussões foram variadas junto às colônias americanas recém-libertadas (COSTA, 2015, p. 5).

O primeiro documento a exibir em sua fundação o princípio da separação de poderes foi a Lei Maior de Massachusetts de 1780, sendo seguida pela carta Política de Virgínia em 1786 e posteriormente a de 1787 . Cabe salientar que essa proposição se propagou pelas outras Constituições dos novos Estados formados no continente americano.

$\mathrm{O}$ texto constitucional Americano pretendeu implementar instrumentos para materializar o princípio da separação de poderes, alcançando na dissociação da autoridade 
uma maneira efetiva de censurar o seu desempenho totalitário. Tal modificação é intitulada como sistema de freios e contrapesos ("checks and balances").

Por serem eficazmente impedidos e comedidos pelos demais, os poderes são partilhados com uma configuração similar e harmônica entre os diversos órgãos pelo sistema de freios e contrapesos sem a contingência de extrapolarem as fronteiras instituídas pela Lei Maior (COSTA, 2015, p. 5).

Na compilação tradicional, The Federalist, Alexander Hamilton e James Madison (2003, p. 39) explanam acerca do sistema dos "checks and balances", descrevendo como os pensadores americanos encontravam-se em perfeita afinidade com os preceitos de Montesquieu, nos seguintes termos:

\begin{abstract}
Para assegurar a separação dos poderes, que todos afirmam ser essencial à manutenção da liberdade, é de toda necessidade que cada um deles tenha uma vontade própria; e, por consequência, que seja organizado de tal modo que aqueles que o exercitam tenham a menor influência possível na nomeação dos depositários dos outros poderes. Isto suposto, e admitida a necessidade da rigorosa observância deste princípio, é necessário que as nomeações para as supremas magistraturas legislativa, executiva e judiciária saiam do povo, que é a fonte primitiva de toda a autoridade.
\end{abstract}

Em vista disso, o sistema de freios e contrapeso englobou uma alteração considerável na separação de poderes estipulando ferramentas que asseguram a sua aplicação concreta. Segundo a ótica de Habermas (2010, p. 301), o legislador não tem capacitação para examinar se os tribunais, ao aderirem o direito, empregam convenientemente os pressupostos normativos que retratam no respaldo supostamente congruente da legislação. Importante mencionar que o controle abstrato de leis é incumbência inquestionável do legislador. Por essa razão, não é inteiramente destituído da acepção de conservar essa função, inclusive em instância superior, a um autodomínio do legislador.

No sentir do supramencionado autor, o deslocamento dessa competência para um tribunal constitucional ocasiona uma justificação difícil. Porque a manifestação em relação aos direitos fundamentais precede-os, não se vinculando, por esse raciocínio, às deliberações executadas no mecanismo legislativo. Assim, o mais relevante item de ligação para a alegação jurídica integral, ou seja, a norma comum e moderadamente efetiva, não é firmada no discurso. Diversamente, surgem as imposições dos direitos fundamentais, muito amplas, intangíveis e impregnadas de convicções. Alexy cita o "discurso dos direitos fundamentais" a todos os comandos da jurisdição constitucional. Apenas na conjuntura do controle abstrato de leis, há um afastamento da validade de normas em algumas circunstâncias específicas (HABERMAS, 2010, p. 301).

Andrei Korner entende que o problema do ativismo judicial é simplificado por colocar em segundo plano o caráter institucional, política e socialmente inserido dos tribunais. Não se esclarece a maneira como os processos incidem sobre a ordem constitucional. Ele reafirma que a questão central é a relação entre direito e democracia. Apresenta em seu quadro de análise que em grande parte o ativismo deu-se no sentido das elites jurídicas voltarem-se a promover as políticas do governo. Constatando que mais recentemente o ativismo manifesta-se nas tensões "entre os regimes governamental e jurisprudencial, os conflitos entre juízes e governo.” (2013, p. 85).

Independente de ser favorável ou contrário às políticas governamentais entende-se que a contaminação, ou colonização do judiciário pela lógica do poder político partidário, já o 
coloca em desacordo com seu papel constitucional fundamental, qual seja o papel de guardião da ordem constitucional.

\section{LIMITES DA INTERPRETAÇÃO CONSTITUCIONAL E CONTROLE DE CONSTITUCIONALIDADE NO CONTEXTO DO ATIVISMO JUDICIAL}

Em concordância com os ensinamentos de Habermas (1997, p. 297) a teoria do direito de Dworkin exerceu o papel de um elo de ligação para apreciar a dificuldade da coerência da jurisdição, cujas escolhas devem ser contempladas, juntamente, a parâmetros de estabilidade do direito e da concordância congruente. Essa ideia edificadora do direito corrente é reexaminada aderindo um alicerce procedimentalista, ou melhor, os requisitos elaborados que acompanham o nascimento da teoria e foram transpostos para a matéria formadora de conjecturas práticas essenciais do debate jurídico.

Entretanto, Habermas (2010, p. 297) afirma que não houve a resolução da indagação a seguir:

[...] de que modo tal prática de interpretação, que procede construtivamente, pode operar no âmbito da divisão de poderes do Estado de direito, sem que a justiça lance mão de competências legisladoras (o que a faria soterrar a ligação estrita que deve haver entre a administração e a lei)?

Ademais, o ordenamento jurídico e a legislação servem de embasamento para a execução de deliberações e a coerência dos atos jurisdicionais submetem-se à validade das normas jurídicas atuais. Com base no princípio da separação de poderes, o Judiciário não participa no procedimento legislativo e necessita que este seja providenciado de maneira lógica. Outras vezes, sob o ângulo da matéria constitucional, o debate na seara política e o mecanismo de formulação de leis estabelecem um conteúdo relevante da dogmática jurídica; apesar disso, as atividades políticas serão consideradas pela teoria do direito por ocasião do desenvolvimento e da aplicação da jurisprudência (HABERMAS, 2010, p. 297).

Fundado nessa conjuntura, aparece a questão do ativismo judicial que:

[...] se mostra como um fenômeno bem distinto da judicialização. Ele nasce no fim do constitucionalismo liberal e início do constitucionalismo social, cujo marco temporal foram as Constituições do México de 1917 e de Weimar de 1919. Mas ganha espaço após a Segunda Grande Guerra, sobretudo nos EUA, com o advento da Corte Warren, mas, aos poucos, a discussão acerca da legitimidade dessa forma de atuação avançou pelo mundo. Essa expressão é comumente utilizada de maneira ambígua ou, no mínimo, dispersa e desencontrada; às vezes, com destaque para um perfil aditivo inesperado. Em outras, com ênfase na ausência de lei embasadora da decisão; ou também revelando um perfil negativo em relação à declaração de inconstitucionalidade de normas (atuação contramajoritária51); ou ainda mostrando estreita relação com a participação ativa do Judiciário na proteção dos princípios constitucionais, através do controle da atividade dos demais poderes (notadamente sobre suas omissões). (FERNANDES, 2012, p.259).

A primeira diligência a ser praticada é o controle do status quaestionis. Para tanto, cabe observar as obras dos escritores estadunidenses em relação ao assunto, uma vez que toda a divergência acerca do ativismo judicial representa, de algum modo, uma preocupação verdadeira entre o judicial review e judicial self restraint. Ou seja, entre a necessidade de respeitarem os limites da segmentação de poderes e a viabilidade de suprimirem com as 
normas inconstitucionais. Usando outros vocábulos, o ativismo judicial é, especialmente, um fato concernente às balizas do estudo da Carta Política.

Barroso (2015, p. 441) declara:

[...] a ideia de ativismo judicial está associada a uma participação mais ampla e intensa do Judiciário na concretização dos valores e fins constitucionais, com maior interferência no espaço de atuação dos outros dois Poderes. Em muitas situações, nem sequer há confronto, mas mera ocupação de espaços vazios.

O controle de constitucionalidade gera um inconveniente para o constitucionalismo: o domínio judicial é exercido em detrimento do autogoverno que a sociedade pratica sobre suas próprias ações, para estipular contenções ao poder estatal. Sendo assim, um dos enfoques contramajoritários do direito constitucional moderno.

Isso é, geralmente, em virtude da evolução concreta e histórica da judicial review, quer dizer, do controle de constitucionalidade no sistema norte-americano. Enfim, é relevante destacar que a Constituição Ianque não considera a hipótese de verificação de constitucionalidade e nem mesmo os limites de sua execução, de maneira oposta à lei Maior brasileira de 1988 .

Christopher Wolfe (1994, p. 3-4) revela três amplas etapas nessa engrenagem de ascensão, em livro sobre a temática. A primeira parte abrange desde o surgimento da Constituição até o concreto estabelecimento da judicial review, com o antecedente Marbury vs. Madison. A fase seguinte, de vertente mais restritiva, é determinada, de um lado, pelo emprego gradativo da posição inicial no controle de constitucionalidade das normas e atos do governo e, do outro, pela decadência da judicial review. Além do mais, o terceiro momento se consolida com o início na segunda metade do século XX, com um desempenho cada vez mais competente da Suprema Corte dos EUA, na tutela de direitos, assegurando, inclusive, aqueles que não constam expressamente na Carta Política. Cabe frisar que esse período foi caracterizado pelas deliberações favoráveis à eliminação das segregações raciais e sexistas, as quais tinham por tônica a justiça.

Em consonância com uma das vozes mais convictas do ativismo judicial, Gerald Walpin (2013, p. 39), os magistrados da Suprema Corte precisam se sujeitar aos mandamentos da Constituição, abolindo normas que sejam incompatíveis com a sua redação e manifestar a constitucionalidade das legislações que não recaiam nessas imperfeições, sem ter em mente as suas convicções particulares. Caso contrário, esses árbitros agirão de maneira militante quando utilizarem as suas propensões ou posicionamentos pessoais de como deveriam ser o ordenamento jurídico, extinguindo as leis que não sejam antagônicas ao texto da Constituição ou ocasionando atuais imposições, novos direitos e encargos, sem qualquer cuidado ou aquiescência constitucional.

Na compreensão de Walpin (2013, p. 41), uma pesquisa histórica dos vereditos mais importantes da Suprema Corte norte-americana exterioriza que, em diversas ocasiões, os seus magistrados não pronunciavam as demandas apresentadas com embasamento na Constituição, evidenciando pontos de vista com fundamento em suas perspectivas políticas e sociais pessoais, contrariando dessa forma, em último juízo, o compromisso que os autorizou a ocupar o cargo. No mesmo sentido, Barroso (2015, p. 460) sustenta:

Não é verdade que o Direito seja um sistema de regras e princípios harmônicos, do qual um juiz imparcial e apolítico colhe as soluções adequadas para os problemas, livre de influências externas. Essa é uma fantasia do formalismo jurídico. Decisões judiciais refletem as preferências pessoais dos juízes, proclama o realismo jurídico;

Revista Brasileira de Teoria Constitucional | e-ISSN: 2525-961X | Encontro Virtual | v. 7 | n. 1 | p. $24-38$ | Jan/Jul. 2021. 
são essencialmente políticas, verbera a teoria crítica; são influenciadas por inúmeros fatores extrajurídicos, registram os cientistas sociais.

Isso posto, percebe-se, a ação contramajoritária, como a indicação de direitos fundamentais em oposição a maiorias democráticas, materializadas por intermédio da judicial review, sendo estas imprescindíveis em uma democracia, tal qual a brasileira. Tornar-se significativo explicitar que efetuar ou não a verificação de constitucionalidade não é um ato qualificador do ativismo judicial, por si só, uma vez que a própria Constituição nacional o considera de maneira taxativa com a norma infraconstitucional especificando suas minúcias.

Com essa racionalidade, não se pode realizar uma analogia entre o ativismo judicial e algumas posições judiciais que são devidamente legítimas, no século XXI, de acordo com a égide da Constituição de 1988. Cabe realçar: o controle dos atos dos Poderes Legislativo e Judiciário, quando aparecerem formal e/ou materialmente opostos ao texto constitucional e à legislação; o exercício contramajoritário do Judiciário para salvaguardar direitos fundamentais contra violações da administração pública ou maior parte procedente da própria coletividade; e o desempenho normativo do STF, na retificação do efeito da imperfeição legislativa nas hipóteses constitucionalmente permitidas, por exemplo, o mandado de injunção.

Tais ações, cujos alicerces se situam na Constituição pátria, externam atos de sujeição e acatamento à ordem democrática. Assim, ocorre a alteração pela ideologia ou pela política, do direito institucionalizado nas normas e na jurisprudência; ainda, pelo moralismo ou pela percepção de justiça.

Com base no ativismo, o Judiciário se expande e ingressa, de forma inadequada, na esfera dos outros Poderes (Legislativo e Executivo). Antes que se rejeite essa assertiva, é patente que o Supremo Tribunal Federal alcança pontualmente a seara do Poder Legislativo quando anuncia inconstitucional uma lei. Logo, é autorizado devido à positivação na Lei Maior por intermédio de ações constitucionais. O que não pode acontecer é o julgamento de casos estruturados em motivos de discordância política ou ideológica com a sua temática, tornando, por conseguinte, uma norma elaborada democraticamente sem concretude (SCHMITZ, 2015, p. 201).

No sentir de Habermas (2010, p. 323):

Uma jurisdição orientada por princípios precisa definir qual pretensão e qual ação deve ser exigida num determinado conflito - e não arbitrar sobre o equilíbrio de bens ou sobre o relacionamento entre valores. É certo que normas válidas formam uma estrutura relacional flexível, na qual as relações podem deslocar-se segundo as circunstâncias de cada caso; porém esse deslocamento está sob a reservada da coerência, a qual garante que todas normas se ajuntam num sistema afinado, o qual admite para casa caso uma única solução correta. A validade jurídica do juízo, tem o sentido deontológico de um mandamento, não o sentido teleológico daqui que é atingível no horizonte dos nossos desejos, sob circunstancias dadas. Aquilo que é melhor para cada um de nós não coincide e o ipso com aquilo que é igualmente bom para todos.

Não é necessário muito intelecto para depreender o seguinte: trata-se, verdadeiramente, do obsoleto problema da discricionariedade judicial no seu pior e mais atual ângulo. Tal dificuldade que rejeita o direito enquanto referência autônoma de normatividade e o submete às regras da política, independentemente da tendência ideológica.

O ativismo judicial é uma conduta facultativa do Poder Judiciário, que na presença do Legislativo e Executivo, traduz-se em uma ingerência desleal. Na conjuntura do common law, o citado instrumento relaciona-se com a divisão easy cases vs hard cases, instituída por 
Herbert Hart. No primeiro é possível a atividade discricionária do magistrado; já no segundo, há uma vedação conforme as restrições estritas da lei e dos precedentes.

A teoria do direito funciona para afastar o exegetismo do juiz bouche de la loi, no seu aspecto hodierno, conservando o acolhimento de um comportamento que propicie utilizar a própria intenção como fator decisivo, perante a complexidade das composições normativas, sobretudo o constitucional. Streck (2018, p. 106) afirma que as diversas decisões proferidas pelos tribunais são destinadas ao desempenho e à concretização dos mandamentos constitucionais conforme as diversificadas concepções que a hermenêutica pode propiciar.

Barroso (2015, p. 443) tece uma crítica de natureza política-ideológica ao ativismo judicial:

Juízes e membros dos tribunais não são agentes públicos eleitos. Sua investidura não tem o batismo da vontade popular. Nada obstante isso, quando invalida atos do Legislativo ou do Executivo ou impõe-lhes deveres de atuação, o Judiciário desempenha um papel que é inequivocamente político. Essa possibilidade de as instâncias judiciais sobreporem suas decisões às dos agentes políticos eleitos gera aquilo que em teoria constitucional foi denominado dificuldade contramajoritária.

Em face disso, a magnitude do embate ao ativismo é a eliminação ao próprio fundamento de excesso judicial, percebido, aqui, como esse artifício arbitrário à vontade. É preciso alterar o pensamento jurídico preponderante, que possui seu suporte na essência de "bom ativismo" e em uma tutela exercida indiferentemente do modo discricionário do controle da justiça. Substituindo como alegação indubitável, que nenhum árbitro - cujo lugar na ordenação judicial pouco interesse - tem o privilégio de ignorar os textos legais. Perante o pretexto de uma Carta Política como a de 1988, todos os julgadores são posicionados "under the rule of law", segundo a indicação de Augusto Zimmermann (2008, p. 41).

Devido a essa situação, uma necessidade premente no Brasil é refletir sobre as cláusulas com as quais habituam-se definir hipóteses de decisão, caso contrário não será possível diminuir o incentivo da parcialidade nos julgamentos e introduzir o país, absolutamente, na direção da democracia. Em conformidade com o significado ativista, a qualificação do direito decorre da "cabeça" e do "coração" do togado, como se a percepção das composições pertencesse apenas aos seus hermeneutas e por si só não existissem.

Bernardo Schmidt Teixeira Penna, após estudo que analisou o Recurso Extraordinário 363889, julgado pelo pleno do STF em 02/06/2011, sobre ações de investigação de paternidade, reafirma que: "Não se pode relegar a decisão judicial aos caprichos, impressões, contingências, convicções e experiências pessoais do julgador." (2016, p.72). Por este motivo, entende que é imperiosa uma nova teoria da decisão judicial que afaste $o$ ativismo judicial.

O entendimento do ativismo judicial, não por casualidade, orienta sempre as contendas a respeito da apropriada atribuição ou do desempenho dos magistrados. Quando se menciona tal instituto, em geral, visualiza uma extrapolação dos limites dos exercícios dos integrantes do Poder Judiciário, a não ser na situação anunciada por Barroso (2015, p. 447) “[...] quando não estejam em jogo os direitos fundamentais ou os procedimentos democráticos, juízes e tribunais devem acatar as escolhas legítimas feitas pelo legislador [...]".

Adeodato (2010, p. 213-214) apresenta o seguinte posicionamento no que concerne à atividade do poder Judiciário: 
[...] cabe ao judiciário aplicar contenciosamente a lei, servindo como elo de ligação entre a norma geral posta pelo legislativo ou executivo e o caso individualizado e único que lhe é levado no conflito concreto. Nesse mister, que só deve exercer quando provocado, espera-se do judiciário uma neutralidade ética e um domínio técnico diante do direito, ou seja, da lei.

Essa é a causa que direciona muitos acadêmicos a caracterizarem o ativismo judicial como uma imperfeição das Cortes em atuar na qualidade de Judiciário. Devido a essa circunstância, os togados procuram apontar alguns elementos que os possam contribuir na atividade jurisdicional, apesar da dificuldade. Em tal busca, descrevem, cabalmente, a necessidade de que as predileções pessoais dos juízes não devem conduzir os julgamentos.

Caso aconteça, em último exame, o ativismo ocasiona a ingerência ilegítima e perigosa do Poder Judiciário em face das demais esferas do Estado. Ademais: a Constituição de 1988 anteviu não só ao domínio forense, mas também aos outros, atribuições específicas, cujo a ação é autorizada, desde que mantenha restrita concordância com os parâmetros delineados pela estrutura constitucional.

Raíssa Stegemann Rocha Creado (2020) em sua dissertação de mestrado enfrenta, a partir da concepção de Habermas, o penoso tema da politização do judiciário brasileiro. Seu trabalho deixa claro que quando um juiz perde a necessária neutralidade, produz efeitos contrários às garantias fundamentais e à democracia.

Georges Abboud em seu artigo "Discricionariedade Administrativa e judicial: o ato administrativo e a decisão judicial" comenta: "se o reforço judicial dos direitos é uma precaução auxiliar contra a tirania dos governos, o controle epistemológico sobre como decidir é outra precaução necessária contra a tirania do Judiciário.” (2014, p.92).

Para alcançar a real incumbência do direito é imprescindível entender o ativismo judicial, fundado no atual status quaestionis e na exigente teoria da decisão. Nenhum sentimento ou interesse de transformação pode transceder o ordenamento jurídico acatado pelas regras democráticas. Assim, juízes não são agentes de mudança da realidade, mas sim defensores do ordenamento jurídico, podendo, aliás, atuar de maneira contramajoritária. Eles garantem os princípios e a segurança na sociedade, de forma a consentir que a alteração da realidade ocorra nas instâncias compatíveis. Por fim, o ativismo pode ser uma trilha prejudicial para fazer valer uma certa opinião política, sem que se percorra o extraordinário e fundamental caminho da discussão.

\section{CONSIDERAÇÕES FINAIS}

O ativismo judicial que vem se consumando, amplamente, é nos últimos tempos uma das mais relevantes pautas da República. Particularmente a partir do posicionamento do Supremo Tribunal Federal em matérias usualmente destinadas ao Poder Legislativo. As investidas, poucas vezes, se atrevem a responsabilizar o próprio poder constituinte originário.

Ele compromete a compreensão da conexão necessária entre o direito de a democracia, constituição e sociedade política. A discricionariedade compromete as garantias fundamentais do direto, pondo-o em concorrência com questões pragmáticas, comprometendo sua interpretação por interesses de grupos e elites instalados no poder. Compromete o princípio da separação dos poderes, por não manter a necessária neutralidade e técnica 
jurídica exigida pelo controle da jurisdição constitucional, comprometendo sua universalidade e legitimidade pactuada no consenso constitucional originário.

Embora tenha a proteção judiciária em sua atividade, nenhum magistrado tem a prerrogativa de confabular contra a Constituição da República, a qual ele asseverou obedecer, zelar e fazer cumprir. De forma concreta, todo o sistema jurídico suporta derrotas e o Estado desmorona quando a Suprema Corte, em especial, se desqualifica como elemento constituído do Poder Judiciário.

Nessas disposições, o ativismo judicial se destaca com uma considerável carga política, uma certa inclinação organizada se manifesta categoricamente, e se torna mais perceptível do que a utilização esperada da tecnicalidade dependente que o exercício jurisdicional, em resumo, deve detalhar para exercer a sua tradicional função institucional.

No limite, o ativismo judicial não encontra pauta sequer na instrução dos objetos, na sua ordem natural, mas na espiritualidade para o bem ou para o mal do juiz, sendo que a atribuição principal deste é a efetivação da Constituição e das leis. Em relação ao questionamento elaborado na introdução, apurou-se que a atuação ativista dos magistrados, com decisões baseadas apenas em posições políticas e ideológicas, representa um perigo sério ao Estado Democrático de Direito.

\section{REFERÊNCIAS}

ABBOUD, Georges. Discricionariedade Administrativa e Judicial: $\mathrm{O}$ ato administrativo e a decisão judicial. São Paulo: Revista dos Tribunais, 2014.

ACKERMAN, Bruce. Nós, o povo soberano: fundamentos de direito constitucional. Trad. Mauro Raposo de Mello. Belo Horinzonte: Del Rey, 2006.

ADEODATO, João Maurício. A retórica constitucional (sobre tolerância, direitos humanos e outros fundamentos éticos do direito positivo). 2. ed. São Paulo: Saraiva, 2010.

BARROSO, Luís Roberto. Curso de direito constitucional contemporâneo: os conceitos fundamentais e a construção do novo modelo. 5. ed. São Paulo: Saraiva, 2015.

BRASIL. Constituição da República Federativa do Brasil de 1988. Disponível em: http://www.planalto.gov.br/ccivil_03/constituicao/constituicao.htm. Acesso em: 28 nov. 2020.

CARVALHO, J. B. C. L. d. Sobre os limites da argumentação jurídica: a desconstrução do ativismo judicial fundado na ponderação de princípios e a reinvenção da legitimidade jurídica nos pensamentos de Jürgen Habermas e Chantal Mouffe. Prisma Jur., São Paulo, v. 12, n. 2, p. 649-710, jul./dez. 2013.

COSTA, Valquíria. A Separação de Poderes: de Montesquieu a Bruce Ackerman, uma mudança no paradigma. Revista de Direito Constitucional e Internacional. São Paulo, n. 93, out./dez. 2015. Disponível em: https://irp-

cdn.multiscreensite.com/0a8b54ec/files/uploaded/A\%20separa\%C3\%A7\%C3\%A3o\%20de\% 20poderes.pdf. Acesso em: 27 nov. 2020. 
CREADO, Raíssa Stegemann Rocha. A politização do judiciário na democracia brasileira sob o crivo da teoria democrática deliberativa de Habermas 2020. 209f Dissertação (Mestrado em Direito). Centro Universitário Salesiano de São Paulo. 2020.

DECLARAÇÃO DE DIREITOS DO HOMEM E DO CIDADÃO - 1789. Disponível em: http://www.direitoshumanos.usp.br/index.php/Documentos-anteriores-\%C3\%A0cria\%C3\%A7\%C3\%A3o-da-Sociedade-das-Na\%C3\%A7\%C3\%B5es-at\%C3\%A91919/declaracao-de-direitos-do-homem-e-do-cidadao-1789.html. Acesso em: 28 out. 2020.

FERNANDES, Ricardo Vieira de Carvalho. Ativismo Judicial: por uma delimitação conceitual à brasileira. Direitos Culturais, Santo Ângelo, v.7, n.12, p. 249-268, jan./jun. 2012.

FERREIRA FILHO, Manoel Gonçalves. Curso de direito constitucional. 35. ed. São Paulo: Saraiva, 2009.

FUX, Luiz. Soberania popular e cidadania foram destaques de palestra de Luiz Fux em fórum internacional. Supremo Tribunal Federal, nov. 2020. Disponível em:

http://portal.stf.jus.br/noticias/verNoticiaDetalhe.asp?idConteudo=455455\&ori=1. Acesso em: 29 nov. 2020.

HABERMAS, Jürgen. Direito e democracia: entre facticidade e validade. Vol. I. Tradução: Flávio Beno Siebeneichler. Rio de Janeiro: Tempo Brasileiro, 2010.

HAMILTON, Alexander; JAY, John; MADISON, James. O federalista. Trad. Hiltomar Martins Oliveira. Belo Horizonte: Líder, 2003.

KOERNER, Andrei. Dossiê: 25 anos da constituição de 1988, Novos estud. - CEBRAP $\mathrm{n}^{\circ}$ 96 São Paulo jul. 2013, p. 69 - 85.

MENDES, Gilmar Ferreira; COELHO, Inocêncio Mártires; BRANCO, Paulo Gustavo Gonet. Curso de Direito Constitucional. 4. ed. São Paulo: Saraiva, 2009.

MONTESQUIEU, Charles de Secondat, Baron de. O espírito das leis. São Paulo: Martins Fontes, 2000.

NINO, Carlos Santiago. La Constitución de la democracia deliberativa. Barcelona: Gedisa, 1997.

PEIXINHO, Manoel Messias. O Princípio da Separação dos Poderes, a judicialização da política e direitos fundamentais. Revista de Direitos e Garantias Fundamentais. n. 4. Vitória, jul-dez. 2008, p. 13-44.

PENNA B. S. T. Papel criador do interprete X papel criativo do interprete dois casos paradigmáticos do ativismo. Revista de Direito da Faculdade Guanambi, v. 3, n. 1, julho dezembro 2016, p. 57- 74. 
SCHMITZ, Leonard. Fundamentação das decisões judiciais: A crise na construção de respostas no processo civil. São Paulo: Editora Revista dos Tribunais, 2015.

STRECK, Lenio Luiz. Jurisdição Constitucional. 5. ed. Rio de Janeiro: Forense, 2018. Ebook.

WALPIN, Gerald. The Supreme Court vs. the Constitution. New York: Significance Press, 2013.

WOLFE. Christopher. The rise of modern judicial review: from constitutional interpretation to judge-made law. New York: Rowman \&

Littlefield Publishers, 1994.

VANZELLA, José Marcos Miné; MARQUETTE, Felipe Rotta. Compreendendo a sociedade civil e a esfera pública política de Habermas. Revista Direito \& Paz, São Paulo, v.2, n. 39, dez. 2018. Disponível em:

http://www.revista.unisal.br/lo/index.php/direitoepaz/article/view/1054/433. Acesso em: 28 nov. 2020.

ZIMMERMANN, Augusto. How brazilian judges undermine the Rule of Law: a critical appraisal. International Trade and Business Law Review, vol. 11, 2008. 